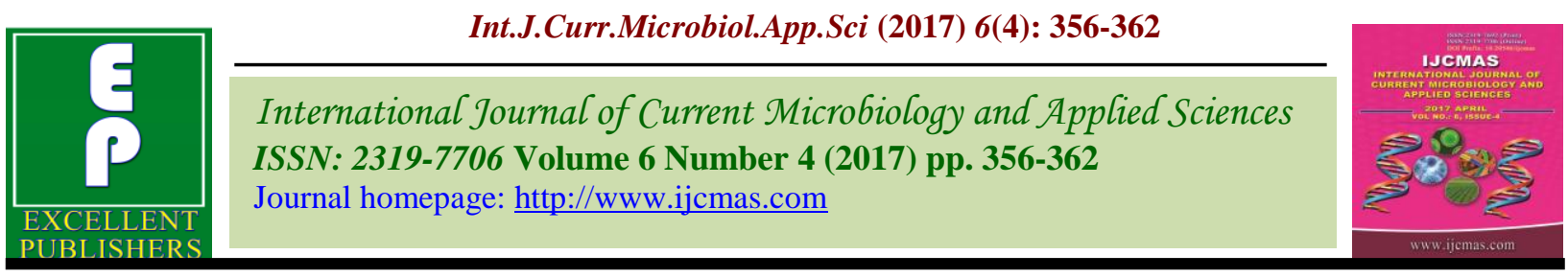

Original Research Article

https://doi.org/10.20546/ijcmas.2017.604.039

\title{
Contract Farming in Turmeric Cultivation and Constraints of the Growers
}

\author{
D.V.Singh ${ }^{1 *}$ and Anupam Mishra ${ }^{2}$ \\ ${ }^{1}$ Senior Scientist and Head, KVK, Kandhamal, OUAT, Bhubaneswar, India \\ ${ }^{2}$ Director, ICAR- ATARI, Zone-VII, Jabalpur, India \\ *Corresponding author
}

\begin{tabular}{|c|c|}
\hline & \multirow{7}{*}{$\begin{array}{l}\text { Contract farming in turmeric cultivation has gained momentum in Kandhamal district after } \\
\text { establishment of the species industry in cooperative sector. It has been realized that the } \\
\text { contracted farmers are being faced much constraints and feel doubt for the sustainability of } \\
\text { the contract farming system in turmeric cultivation. A study conducted with each of } 80 \\
\text { contracted and non-contracted turmeric growers from four panchayats of two blocks in } \\
\text { Kandhamal districts of Odisha revealed that no insurance coverage, transparency in } \\
\text { measurement, written agreement, clarification and understanding on suggested } \\
\text { technologies, exposure visit to develop confidence, as well as flexibility in repayment of } \\
\text { loan, sale price not fixed over the production cost, harassment in payment, produce not } \\
\text { timely lifted, incompetent field staffs along with non-cooperative attitude and frequent } \\
\text { transfer, fertilizers and bio fertilizers not supplied in time were the pertinent constraints } \\
\text { expressed by both the contracted and non-contracted respondents. The findings therefore } \\
\text { suggested that the contracting spices industry officials have to analyze all these constraints } \\
\text { and extend possible supports to develop harmonious relationship benefitting both the } \\
\text { contracted growers and contracting spices industry as well as sustainability of the contract } \\
\text { farming in turmeric cultivation. }\end{array}$} \\
\hline & \\
\hline & \\
\hline & \\
\hline Article Info & \\
\hline & \\
\hline & \\
\hline
\end{tabular}

\section{Introduction}

Contract farming is a contract between a producer particularly farmer and a purchaser established in advance of the growing season for specific quantity and date of delivery of an agricultural output at a price formula fixed in advance. It varies depending on the nature and type of contracting agency, technology, nature of crop or produce and the local or national context. The essential pre-condition is that there must be a market for the product that will ensure profitability of the venture (Asokan and Singh, 2003). Besides; physical, social and cultural environment, land availability and needed inputs, sustainability of utilities and land availability and needed inputs and communication network are other factors that management must have necessary competency and structure to handle the firm involving many small farmers. Contracts are also need to be backed up by law and efficient legal systems (Kumar, 2002). There is also risk factor of desired production with quality specifications (Gupta, 2002). Unsuitable technology, crop incompatibility, monopoly of the sponsors, exploitation by field staffs, not cooperating for timely harvest, immediate lifting and improper guidance etc. are other factors of constraints (Chawea, 2002; Kumar and Singh, 2005). 
Contract farming in turmaric cultivation has gained popularity in Kandhaml district of Odisha after establishment of spices industry in cooperative sector. It has been realized that the farmers are facing much constraints and feel doubt for the sustainability of the contract farming in turmeric cultivation for which the present study was designed.

\section{Materials and Methods}

Turmeric is being traditionally grown in Kandhamal district of Odisha and considered as an important spices and case crop. Kandhamal Apex Spices Association for Marketing has introduced contract farming system for which the district Kandhamal was selected purposively. A sample size of 80 each contracted and non-contracted turmeric farmers from four panchayats of Daringibadi and Tumadibada blocks were selected randomly as the respondents for the study. The data was collected personally during 2015 through a semi-structured schedule pretested earlier. Information collected on scale point of strongly agree, agree and disagree were analyzed with score value of 3 , 2 and 1 respectively to reveal the results.

\section{Results and Discussion}

Planning is the most fundamental functions of management. Effective planning provides cooperative and coordinated efforts as well as facilitates timely execution of tasks and reduces uncertainties. It also make easy in effective programme implementation and thus proceeds to all managerial functions. Community organisation, cluster approach, written agreements, distributing responsibility and involving growers in decision making process are the pertinent factors that are essential in planning. As observed from table 1 significant differential opinion were observed through critical ratio test among the contracted and non-contracted respondents on not involving in decision making process and non-clarification on responsibility where the contracted respondents were not agreed along with no community organization. No written agreements, cluster approach not followed and to some extent not involving in decision making process as well as not concern for feasible technology were the constraints observed in planning.

Quality production and productivity largely depend on use of the recommended inputs. The contracting firms are always concerned with quality and desired production for which they supply quality seed and other recommended crop inputs. Significant differential opinions were observed on (Table 2) not supplying recommended quantity, quality not ensured, no skill development in use and informing date of supply where contracted respondents were not agreed. Both the contracted and non-contracted respondents had stated the constraints of not supplied in time and not organizing farmer to apply at a time for better management and achieving the desired results. The pooled mean score value indicated that not supplying required quantity and in time as well as not organizing farmers to apply at a time were the constraints stated by the respondents in input supply.

Majority of the small producers experiences difficulties in availing credit for the production units. Contract farming usually allows access of the farmers to some form of credit to purchase additional inputs. In most cases, the sponsors usually provide credit or supply required inputs to the contracted growers. If not, arrangements are to be made with the credit institutions for financial support. The findings of the study revealed (Table 3) that both the contracted and noncontracted respondents were of similar opinions except not liaoning with credit institutions where the contracted respondents 
not agreed. The contracted respondents were also not agreed for the constraints of high rate of interest and no subsidy facility. In other words, no insurance converge, flexibility in repayment as well as adequate credit not available were the major constraints expressed by both the contracted and noncontracted respondents.

Small scale farmers are frequently reductant to adopt new technologies because of possible risks and uncertainties. Regular technological backstopping is therefore necessary to enrich knowledge and skill competency as well as developing confidence on new technologies advocated. Turmeric is traditionally grown in the study area and farmers have accumulated experience in cultivation. Therefore, they had not stated the constraints (Table 4) of not liasoning with the source of information, no attempt to solve technological problems, inadequate training and no supply of reference materials. Rather, they essentially need exposure visit to ideal situations for developing confidence on new technologies as well as clarifications and understanding on the suggested technologies and expressed the constraints under technological backstopping.

Field staffs employed by the contracting firms are the key link and have direct interface between the sponsoring organizations and contracted farmers. These staffs should have good understanding on crop management, ability to communicate effectively and build capability of the growers. The study revealed (Table 5) that both the contracted and noncontracted respondents were of similar opinions. Though the respondents had stated all the constraints mentioned in the table, constraints on irregular monitoring and supervision, no timely diagnosis of problems and no conflict resolutions were not pertinent. In other words, recruitment of competent and cooperative field staffs along with restricting their frequent transfer from the area must be taken care by the contracting firm as the respondents felt the constraints of inadequate management support.

Table.1 Constraints expressed on planning

\begin{tabular}{|l|l|l|l|l|l|l|}
\hline S. & Constraint & \multicolumn{2}{|l|}{ Mean Score } & $\begin{array}{l}\text { Diff. } \\
\mathbf{( \% )}\end{array}$ & $\begin{array}{l}\text { C.R. } \\
\text { Value }\end{array}$ & $\begin{array}{l}\text { Pooled } \\
\text { Mean } \\
\text { Score } \\
\text { (n=160) }\end{array}$ \\
\cline { 3 - 7 } & $\begin{array}{l}\text { Contracted } \\
\text { farmers } \\
(\mathbf{n = 8 0})\end{array}$ & $\begin{array}{l}\text { Non-contracted } \\
\text { farmers } \\
(\mathbf{n = 8 0})\end{array}$ & 2.25 & 13.78 & 0.137 & 2.10 \\
\hline 1. & $\begin{array}{l}\text { No community } \\
\text { organization }\end{array}$ & 1.94 & 2.54 & 18.92 & $0.203 *$ \\
$*$ & 2.28 \\
\hline 2. & $\begin{array}{l}\text { Not involving in } \\
\text { decision making } \\
\text { process }\end{array}$ & 2.06 & 2.69 & 4.83 & 0.051 & 2.63 \\
\hline 3. & $\begin{array}{l}\text { Cluster approach not } \\
\text { followed }\end{array}$ & 2.56 & 2.44 & 18.44 & $0.193 *$ & 2.22 \\
\hline 4. & $\begin{array}{l}\text { No clarification on } \\
\text { responsibility }\end{array}$ & 1.99 & 2.85 & 04.21 & 0.046 & 2.79 \\
\hline 5. & $\begin{array}{l}\text { No written } \\
\text { agreements }\end{array}$ & 2.73 & 2.35 & 07.23 & 0.072 & 2.27 \\
\hline 6. & $\begin{array}{l}\text { Not concern for } \\
\text { feasible technology }\end{array}$ & 2.18 & & & \\
\hline
\end{tabular}

(Maximum obtainable score-3) ** Significant at 0.01 level, *Significant at 0.05 level 
Table.2 Constraints expressed on input supply

\begin{tabular}{|c|c|c|c|c|c|c|}
\hline \multirow{2}{*}{$\begin{array}{l}\text { S. } \\
\text { No. }\end{array}$} & \multirow[t]{2}{*}{ Constraint } & \multicolumn{2}{|c|}{ Mean Score } & \multirow{2}{*}{$\begin{array}{l}\text { Diff. } \\
(\%)\end{array}$} & \multirow{2}{*}{$\begin{array}{l}\text { C.R. } \\
\text { Value }\end{array}$} & \multirow{2}{*}{$\begin{array}{c}\text { Pooled } \\
\text { Mean } \\
\text { Score } \\
(n=160)\end{array}$} \\
\hline & & $\begin{array}{l}\text { Contracted } \\
\text { farmers } \\
(\mathbf{n}=\mathbf{8 0})\end{array}$ & $\begin{array}{c}\text { Non- } \\
\text { contracted } \\
\text { farmers } \\
(\mathbf{n}=\mathbf{8 0})\end{array}$ & & & \\
\hline 1. & $\begin{array}{l}\text { Not supplying } \\
\text { recommended } \\
\text { quantity }\end{array}$ & 2.11 & 2.76 & 23.55 & $0.266^{* *}$ & 2.44 \\
\hline 2. & Not supplied in time & 2.35 & 2.75 & 14.55 & 0.161 & 2.55 \\
\hline 3. & Quality not ensured & 1.80 & 2.63 & 31.56 & $0.356^{* *}$ & 2.11 \\
\hline 4. & $\begin{array}{l}\text { No skill } \\
\text { development in use }\end{array}$ & 1.58 & 2.23 & 29.18 & $0.300 * *$ & 1.91 \\
\hline 5. & $\begin{array}{l}\text { Not organizing } \\
\text { farmers to apply at a } \\
\text { time }\end{array}$ & 2.48 & 2.55 & 02.75 & 0.028 & 2.52 \\
\hline 6. & $\begin{array}{l}\text { Not informing date } \\
\text { of supply }\end{array}$ & 1.71 & 2.45 & 30.20 & $0.328^{* *}$ & 2.08 \\
\hline
\end{tabular}

(Maximum obtainable score-3) ** Significant at 0.01 level

Table. 3 Constraints on credit and finance

\begin{tabular}{|c|c|c|c|c|c|c|}
\hline \multirow{2}{*}{$\begin{array}{l}\text { S. } \\
\text { No. }\end{array}$} & \multirow[t]{2}{*}{ Constraint } & \multicolumn{2}{|c|}{ Mean Score } & \multirow{2}{*}{$\begin{array}{l}\text { Diff. } \\
(\%)\end{array}$} & \multirow{2}{*}{$\begin{array}{l}\text { C.R. } \\
\text { Value }\end{array}$} & \multirow{2}{*}{$\begin{array}{l}\text { Pooled } \\
\text { Mean } \\
\text { Score }\end{array}$} \\
\hline & & $\begin{array}{c}\text { Contracted } \\
\text { farmers } \\
(\mathbf{n}=\mathbf{8 0})\end{array}$ & $\begin{array}{c}\text { Non- } \\
\text { contracted } \\
\text { farmers } \\
(\mathbf{n}=\mathbf{8 0})\end{array}$ & & & \\
\hline 1. & $\begin{array}{l}\text { Not liaoning with } \\
\text { credit institutions }\end{array}$ & 1.70 & 2.29 & 25.76 & $0.266^{* *}$ & 2.00 \\
\hline 2. & $\begin{array}{l}\text { Adequate credit not } \\
\text { available }\end{array}$ & 2.33 & 2.41 & 03.32 & 0.033 & 2.37 \\
\hline 3. & High rate of interest & 1.73 & 2.03 & 14.78 & 0.140 & 1.88 \\
\hline 4. & $\begin{array}{l}\text { No flexibility in } \\
\text { repayment }\end{array}$ & 2.63 & 2.61 & 00.76 & 0.008 & 2.62 \\
\hline 5. & No insurance coverage & 3.00 & 3.00 & 00.00 & 0.000 & 3.00 \\
\hline 6. & No subsidy facility & 1.73 & 2.03 & 14.78 & 0.140 & 1.88 \\
\hline
\end{tabular}

(Maximum obtainable score-3) ** Significant at 0.01 level 
Table.4 Constraints expressed on technological backstopping

\begin{tabular}{|c|c|c|c|c|c|c|}
\hline \multirow{2}{*}{$\begin{array}{l}\text { SI. } \\
\text { No. }\end{array}$} & \multirow[t]{2}{*}{ Constraint } & \multicolumn{2}{|c|}{ Mean Score } & \multirow{2}{*}{$\begin{array}{c}\text { Diff. } \\
(\%)\end{array}$} & \multirow{2}{*}{$\begin{array}{l}\text { C.R. } \\
\text { Value }\end{array}$} & \multirow{2}{*}{$\begin{array}{c}\text { Pooled } \\
\text { Mean } \\
\text { Score } \\
(n=160)\end{array}$} \\
\hline & & $\begin{array}{c}\text { Contracted } \\
\text { farmers } \\
(\mathbf{n}=\mathbf{8 0})\end{array}$ & $\begin{array}{c}\text { Non- } \\
\text { contracted } \\
\text { farmers } \\
(\mathbf{n}=\mathbf{8 0})\end{array}$ & & & \\
\hline 1. & Inadequate training & 2.06 & 2.03 & 1.46 & 0.013 & 2.05 \\
\hline 2. & $\begin{array}{l}\text { No supply of reference } \\
\text { materials }\end{array}$ & 2.18 & 1.90 & 12.48 & 0.125 & 2.04 \\
\hline 3. & No exposure visit & 2.60 & 2.78 & 06.47 & 0.070 & 2.69 \\
\hline 4. & $\begin{array}{l}\text { No clarification and } \\
\text { understanding }\end{array}$ & 2.65 & 2.75 & 03.64 & 0.039 & 2.70 \\
\hline 5. & $\begin{array}{l}\text { Not liasoning with } \\
\text { source of information }\end{array}$ & 1.73 & 1.96 & 11.73 & 0.018 & 1.85 \\
\hline 6. & $\begin{array}{l}\text { No attempt to solve } \\
\text { technological } \\
\text { problems }\end{array}$ & 1.49 & 1.68 & 11.31 & 0.096 & 1.59 \\
\hline
\end{tabular}

(Maximum obtainable score -3 )

Table.5 Constraints on management support

\begin{tabular}{|c|c|c|c|c|c|}
\hline \multirow{2}{*}{$\begin{array}{c}\text { S. } \\
\text { No } \\
\cdot\end{array}$} & \multirow[t]{2}{*}{ Constraint } & \multicolumn{2}{|c|}{ Mean Score } & \multirow{2}{*}{$\begin{array}{l}\text { Diff. } \\
(\%)\end{array}$} & \multirow{2}{*}{$\begin{array}{c}\text { Pooled } \\
\text { Mean } \\
\text { Score } \\
(\mathrm{n}=160)\end{array}$} \\
\hline & & $\begin{array}{c}\text { Contracted } \\
\text { farmers } \\
(\mathbf{n}=\mathbf{8 0})\end{array}$ & $\begin{array}{c}\begin{array}{c}\text { Non- } \\
\text { contracted } \\
\text { farmers } \\
(\mathbf{n}=\mathbf{8 0})\end{array} \\
\end{array}$ & & \\
\hline 1. & $\begin{array}{l}\text { Irregular monitoring and } \\
\text { supervision }\end{array}$ & 2.11 & 2.26 & 6.64 & 2.19 \\
\hline 2. & No timely diagnosis of problems & 2.14 & 2.20 & 2.73 & 2.17 \\
\hline 3. & No conflict resolution & 2.08 & 2.18 & 4.59 & 2.13 \\
\hline 4. & Frequent change of field staffs & 2.46 & 2.54 & 3.15 & 2.50 \\
\hline 5. & Field staffs not competent & 2.66 & 2.71 & 1.85 & 2.69 \\
\hline 6. & Field staffs not cooperative & 2.40 & 2.48 & 3.23 & 2.44 \\
\hline
\end{tabular}

(Maximum obtainable score-3) 
Table.6 Constraints on procurement and payment

\begin{tabular}{|c|c|c|c|c|c|c|}
\hline \multirow{2}{*}{$\begin{array}{l}\text { S. } \\
\text { No. }\end{array}$} & \multirow[t]{2}{*}{ Constraint } & \multicolumn{2}{|c|}{ Mean Score } & \multirow{2}{*}{$\begin{array}{l}\text { Diff. } \\
(\%)\end{array}$} & \multirow{2}{*}{$\begin{array}{c}\text { C.R. } \\
\text { Value }\end{array}$} & \multirow{2}{*}{$\begin{array}{c}\text { Pooled } \\
\text { Mean } \\
\text { Score } \\
(n=160\end{array}$} \\
\hline & & $\begin{array}{c}\text { Contracted } \\
\text { farmers } \\
(\mathbf{n}=\mathbf{8 0})\end{array}$ & $\begin{array}{c}\text { Non- } \\
\text { contracted } \\
\text { farmers } \\
(\mathbf{n}=\mathbf{8 0})\end{array}$ & & & \\
\hline 1. & $\begin{array}{l}\text { Not insisting for } \\
\text { timely harvesting }\end{array}$ & 2.63 & 2.75 & 4.36 & 0.047 & 2.69 \\
\hline 2. & $\begin{array}{l}\text { Produce not timely } \\
\text { lifted }\end{array}$ & 2.65 & 3.00 & 11.67 & 0.133 & 2.83 \\
\hline 3. & $\begin{array}{l}\text { Harassment inlifting } \\
\text { the produce }\end{array}$ & 2.26 & 2.85 & 20.70 & $0.236^{* * *}$ & 2.56 \\
\hline 4. & $\begin{array}{l}\text { No transparency in } \\
\text { measurement }\end{array}$ & 2.98 & 3.00 & 00.67 & 0.007 & 2.99 \\
\hline 5. & $\begin{array}{l}\text { Sale price not fixed } \\
\text { over production }\end{array}$ & 2.98 & 2.98 & 00.00 & 0.000 & 2.98 \\
\hline 6. & $\begin{array}{l}\text { Harassment in } \\
\text { payment }\end{array}$ & 2.70 & 3.00 & 10.00 & 0.114 & 2.85 \\
\hline
\end{tabular}

(Maximum obtainable score-3) ** Significant at 0.01 level

Timely harvesting and immediate lifting are essential to maintain quality. Besides, the contracted farmers need immediate payment for repayment of the loan availed as well as investment in other farm activities. Both the contracted and non-contracted respondents had stated more of constraints on procurement and payment (Table 6). The constraints were no transparency in measurement, sale price not fixed over the production cost, harassment in payment and lifting the produce as well as not insisting for timely harvest and lifting of the produce. These supports are very much essential for the benefit of the contracted growers and contracting firms failing which sustainability of the contract farming may be doubtful.

In conclusion well managed contract farming is an effective way to coordinate and promote production and marketing in agriculture. Critics of contract farming tend to emphasis the inequality of the relationships and stronger position of the sponsors in comparison to growers. The study revealed that no insurance coverage, no transparency in measurement, sale price not fixed over the production cost, harassment in payment, produce not timely lifted, no written agreement, no clarification and understanding on suggested technologies, incompetent field staffs along with their non-cooperation and frequent transfer, not insisting for timely harvesting, no exposure visit to develop confidence, no flexibility in repayment of loan, fertilizers and bio fertilizers not supplied in time were the pertinent constraints expressed by both the contracted and noncontracted turmeric growers under contract farming.

Therefore, the officials of the contracting spices industry have to analyze all these constraints and extend possible supports to coordinate the production activities, procurement of the produce in a transparent and participatory fashion as well as establishing harmonious relationships so that the contracted growers fully understand the obligation of the contracting firm and develop 
interest to involve continuously in the contract farming on sugarcane cultivation.

\section{References}

Asokan, R.S. and Singh, G. 2003. Role and constraints of contract farming in agroprocessing industry, Indian J. Agri. Economics, 58(3): 566-575

Chawla, S. 2002. Contract farming: Partners in progress", Agriculture Today, 18-33.
Gupta, S.K. 2002. Contract farming, National Bank News Rev., 18(1): 64-67.

Kumar, A. 2002. A study on vegetable producing contract farmers of Belgaum district of Karnataka, M.Sc. (Ag) Thesis, (Unpub), UAS, Dharwad, Karnataka.

Kumar, H. and Singh, R. 2005. Success and failure of contract farming in Himachal Pradesh, Indian J. Agri. Marketing, 19(2): 170-176.

\section{How to cite this article:}

Singh, D. V. and Anupam Mishra. 2017. Contract Farming in Turmeric Cultivation and Constraints of the Growers. Int.J.Curr.Microbiol.App.Sci. 6(4): 356-362.

doi: http://dx.doi.org/10.20546/ijcmas.2017.604.039 